\title{
Multilevel educational and motivational intervention in patients after myocardial infarction project - a new approach to improve treatment adherence
}

\author{
Corresponding author: \\ Izabella Uchmanowicz, \\ Wroclaw Medical University, \\ Department of Clinical Nursing, \\ Bartla 5 Str., 51-618 Wroclaw, Poland \\ e-mail: \\ izabella.uchmanowicz@umed.wroc.pl \\ Medical Research Journal 2020; \\ Volume 5, Number 4, 222-224 \\ 10.5603/MRJ.a2020.0046 \\ Copyright (C) 2020 Via Medica \\ ISSN 2451-2591
}

Key words: health education, motivation, adherence to treatment, acute coronary syndrome Med Res J 2020; 5 (4): 222-224
Adherence to treatment and consistent medication-taking are key factors in treatment effectiveness. Patient adherence is affected by their involvement in the treatment process, their understanding of its goals, and their overall wellbeing in the process. Approximately $55 \%$ of the elderly do not comply with the prescribed treatment. Poor medication adherence is known to deteriorate clinical outcome in patients after ACS [1-5].

In the current issue of Medical Research Journal Kubica et al. [6] published the rationale for Multilevel Educational and Motivational Intervention in Patients after Myocardial Infarction (MEDMOTION) project. This previously designed project $[7,8]$ is adopted to support adherence to the study treatment in the Evaluation of Safety and Efficacy of Two Ticagrelor-based De-escalation Antiplatelet Strategies in Acute Coronary Syndrome (ELECTRA-SIRIO 2) trial [9, 10]. The ELECTRA-SIRIO 2 trial is a randomised, multicentre, double-blind, clinical study with a 12 months follow-up testing the de-escalation of antiplatelet treatment strategies in $\mathbf{4 5 0 0}$ patients after acute coronary syndrome.

The MEDMOTION project involves interventions aimed to improve adherence to treatment (patients' education, motivation, reminding to take medications and attend consecutive medical appointments) and multi-faceted, questionnaire-based diagnoses (readiness to discharge from hospital, adherence to treatment and functioning in chronic disease) [11]. A prespecified sub-analysis of the ELECTRA-SIRIO 2 trial to evaluate the impact of the results of MEDMOTION diagnostic questionnaires on the clinical outcomes will be performed.

The financial support received from the Medical Research Agency allows for the first time in Poland to conduct a study of such scale evaluating effects of educational and motivational interventions. The education based on authors' previous experience [12-24], aimed to improve the knowledge and practical skills of patients and their cohabitating family members will be standardized (based on a series of eight brochures developed for the project), and yet individualized (brochures in one workbook will be selected individually depending on the patients' needs). The education started during hospitalisation and continued after discharge is expected to enhance adherence to treatment [25-33]. Patients' education will be supported by a motivational interview conducted by healthcare staff during the initial hospitalization and follow-up visits interventions. An interface available for patients as an online and mobile platform to increase protocol adherence and patient retention is an important element of the MEDMOTION project. Moreover, the system will also provide support to the patient with every day reminding of the need to regularly take drugs and relevant educational content [34-36]. 
The diagnostic part of the project is based on three questionnaires: the Readiness for Hospital Discharge after Myocardial Infarction Scale (RHD-MIS) [37, 38], the Adherence in Chronic Diseases Scale (ACDS) [39, 40] and the Functioning in Chronic Illness Scale (FCIS) [41]. All these tools are expected to reflect the effectiveness of different aspects of patient-medical staff collaboration.

Ensuring good adherence is also a critical issue in randomized clinical trials evaluating treatment strategies, as the intention-to-treat analysis is a widely accepted method for such kind of studies [42-45]. The MEDMOTION project is included as an integral part of the ELECTRA-SIRIO 2 trial to identify patients requiring additional interventions and to ensure the highest quality and reliability of results.

The concept of prolonged educational and motivational interventions beyond the hospitalization period is supported by the report by Kosobucka et al. also published in the current issue of Medical Research Journal [46]. Almost half of the population included into the study were satisfied with the level of their knowledge at the day of discharge from the hospital, while only onefourth of them obtained a high score in the objective assessment of their knowledge. Moreover, the readiness for discharge from the hospital was not shown to affect the implementation of the therapeutic plan in the long-term follow-up after myocardial infarction [15, 46]. These surprising results confirm that patient education should be continued after discharge from the hospital.

Medication adherence is an issue of growing concern. Promoting adherence to medications offers a rare opportunity to simultaneously improve health outcomes while reducing costs $[47,48]$. The education of patients regarding the risks and benefits of treatment is pivotal to avoid premature discontinuation of the medication. Nevertheless, no standard approach has been developed. The complex health education and motivation within the MEDMOTION project started during hospitalisation and continued after discharge, explaining the pathophysiology and symptoms of the disease, elucidating goals and potential benefits of treatment, and highlighting the risk of premature termination of therapy, with use of additional methods helping patients to remember the treatment schedule is expected to enhance treatment adherence.

\section{References}

1. Jankowska-Polańska B, Zamęta K, Uchmanowicz I, et al. Adherence to pharmacological and non-pharmacological treatment of frail hypertensive patients. J Geriatr Cardiol. 2018; 15(2): 153-161, doi: 10.11909/j. issn.1671-5411.2018.02.002, indexed in Pubmed: 29662509.

2. Rajpura J, Nayak R. Medication adherence in a sample of elderly suffering from hypertension: evaluating the influence of illness perceptions, treatment beliefs, and illness burden. J Manag Care Pharm. 2014; 20(1): 58-65, doi: 10.18553/jmcp.2014.20.1.58, indexed in Pubmed: 24511766.
3. Chudiak A, Uchmanowicz I, Mazur G. Relation between cognitive impairment and treatment adherence in elderly hypertensive patients. Clin Interv Aging. 2018; 13: 1409-1418, doi: 10.2147/CIA.S162701, indexed in Pubmed: 30122913.

4. Kubica A, Obońska K, Fabiszak T, et al. Adherence to antiplatelet treatment with P2Y12 receptor inhibitors. Is there anything we can do to improve it? A systematic review of randomized trials. Curr Med Res Opin. 2016; 32(8): 1441-1451, doi: 10.1080/03007995.2016.1182901, indexed in Pubmed: 27112628.

5. Kubica A, Kasprzak M, Siller-Matula J, et al. Time-related changes in determinants of antiplatelet effect of clopidogrel in patients after myocardial infarction. Eur J Pharmacol. 2014; 742: 47-54, doi: 10.1016/j. ejphar.2014.08.009, indexed in Pubmed: 25199965.

6. Kubica A, Adamski P, Bączkowska A, et al. The rationale for Multilevel EDucational and MOtivational intervention in patients after myocardial infarcTION (MEDMOTION) project is to support multicentre randomized clinical trial EvaLuating safety and EffiCacy of two TicagRelor-based de-escalation Ant. Medical Research Journal. 2020, doi: 10.5603/mrj.a2020.0043

7. Kubica A. Rationale of cardiopulmonary resuscitation training as an element of multilevel educational and motivational project (MEDMOTION). Disaster and Emergency Medicine Journal. 2020, doi: 10.5603/demj.a2020.0017.

8. Kubica A, Baczkowska A. Rationale for motivational interventions as pivotal element of multilevel educational and motivational project (MEDMOTION). Folia Cardiologica 2020;15(1):6-10 DOI: 10 5603/FC. ; 2020: 0003, doi: 10.5603/FC.2020.0003.

9. Kubica J, Adamski P, Buszko K, et al. Rationale and Design of the Effectiveness of LowEr maintenanCe dose of TicagRelor early After myocardial infarction (ELECTRA) pilot study. Eur Heart J Cardiovasc Pharmacother. 2018; 4(3): 152-157, doi: 10.1093/ehjcvp/pvx032, indexed in Pubmed: 29040445

10. Kubica J, Adamski P, Buszko K, et al. Platelet inhibition with standard vs. lower maintenance dose of ticagrelor early after myocardial infarction (ELECTRA): a randomized, open-label, active-controlled pharmacodynamic and pharmacokinetic study. Eur Heart J Cardiovasc Pharmacother. 2019; 5(3): 139-148, doi: 10.1093/ehjcvp/pvz004, indexed in Pubmed: 30689800

11. Kubica A. Self-reported questionnaires for a comprehensive assessment of patients after acute coronary syndrome. Medical Research Journal. 2019; 4(2): 106-109, doi: 10.5603/mrj.a2019.0021.

12. Michalski P, Kosobucka A, Pietrzykowski $\measuredangle$, et al. Effectiveness of therapeutic education in patients with myocardial infarction. Medical Research Journal. 2018; 2(3): 89-96, doi: 10.5603/mrj.2017.0011.

13. Kubica A, Pufal J, Moczulska B, et al. Skuteczność edukacji zdrowotnej u osób hospitalizowanych w klinice kardiologii. Psychiatria w Praktyce Ogólnolekarskiej. 2005; 5: 61

14. Kubica A, Kasprzak M, Obońska K, et al. Discrepancies in assessment of adherence to antiplatelet treatment after myocardial infarction. Pharmacology. 2015; 95(1-2): 50-58, doi: 10.1159/000371392, indexed in Pubmed: 25592409.

15. Michalski P, Kasprzak M, Siedlaczek M, et al. The impact of knowledge and effectiveness of educational intervention on readiness for hospital discharge and adherence to therapeutic recommendations in patients with acute coronary syndrome. Medical Research Journal. 2020, doi: 10.5603/mrj.a2020.0023.

16. Pietrzykowski $\nvdash$, Michalski P, Kosobucka A, et al. Knowledge about health and disease in obese patients after myocardial infarction. An observational study. Medical Research Journal. 2018; 2(4): 135-140, doi: 10.5603/mri.2017.0018.

17. Kosobucka A, Michalski P, Pietrzykowski $Ł$, et al. The impact of readiness to discharge from hospital on adherence to treatment in patients after myocardial infarction. Cardiol J. 2020 [Epub ahead of print], doi: 10.5603/CJ.a2020.0005, indexed in Pubmed: 32037501.

18. Kubica A, Kasprzak M, Obońska K, et al. Impact of health education on adherence to clopidogrel and clinical effectiveness of antiplatelet treatment in patients after myocardial infarction. Medical Research Journal. 2016; 3(4): 154-159, doi: 10.5603/fmc.2015.0010.

19. Kosobucka A, Michalski P, Pietrzykowski $\measuredangle$, et al. Adherence to treatment assessed with the Adherence in Chronic Diseases Scale in patients after myocardial infarction. Patient Prefer Adherence. 2018; 12 : 333-340, doi: 10.2147/PPA.S150435, indexed in Pubmed: 29551891

20. Kubica A, Sinkiewicz W, Szymański P, et al. Edukacja zdrowotna w chorobach układu krążenia - możliwości i zagrożenia. Folia Cardiologica Excerpta. 2007; 2: 177

21. Kubica A. Wybrane problemy prewencji wtórnej u chorych po incydentach wieńcowych. Folia Cardiologica Excerpta. 2008; 3: 366.

22. Winter MP, Koziński M, Kubica J, et al. Personalized antiplatelet therapy with P2Y12 receptor inhibitors: benefits and pitfalls. Postepy Kardiol 
Interwencyjnej. 2015; 11(4): 259-280, doi: 10.5114/pwki.2015.55596, indexed in Pubmed: 26677375.

23. Pietrzykowski Ł, Michalski P, Kosobucka A, et al. Medication adherence and its determinants in patients after myocardial infarction. Sci Rep. 2020; 10(1): 12028, doi: 10.1038/s41598-020-68915-1, indexed in Pubmed: 32694522.

24. Kubica A, Kochman W, Bogdan M, et al. The influence of undergone percutaneous coronary interventions, and earlier hospitalizations with myocardial infarction on the level of knowledge and the effectiveness of health education in patients with myocardial infarction. Advances in Interventional Cardiology. 2009; 5: 25-30.

25. Jankowska-Polanska B, Uchmanowicz I, Chudiak A, et al. Psychometric properties of the Polish version of the eight-item Morisky Medication Adherence Scale in hypertensive adults. Patient Prefer Adherence. 2016; 10: 1759-1766, doi: 10.2147/PPA.S101904, indexed in Pubmed: 27672314.

26. Uchmanowicz B, Jankowska EA, Uchmanowicz I, et al. Self-Reported Medication Adherence Measured With Morisky Medication Adherence Scales and Its Determinants in Hypertensive Patients Aged $\geq 60$ Years: A Systematic Review and Meta-Analysis. Fron Pharmacol. 2019; 10: 168, doi: 10.3389/fphar.2019.00168, indexed in Pubmed: 30930769

27. Uchmanowicz I, Hoes A, Perk J, et al. Optimising implementation of European guidelines on cardiovascular disease prevention in clinica practice: what is needed? Eur J Prev Cardiol. 2020 [Epub ahead of print]: 2047487320926776, doi: 10.1177/2047487320926776, indexed in Pubmed: 32486919

28. Jankowska-Polańska B, Blicharska K, Uchmanowicz I, et al. The influence of illness acceptance on the adherence to pharmacological and non-pharmacological therapy in patients with hypertension. Eur J Cardiovasc Nurs. 2016: 15(7): 559-568, doi: 10.1177/1474515115626878, indexed in Pubmed: 26743263.

29. Krzemińska S, Lomper K, Chudiak A, et al. The association of the level of self-care on adherence to treatment in patients diagnosed with type 2 diabetes. Acta Diabetol. 2020 [Epub ahead of print], doi: 10.1007/s00592-020-01628-z, indexed in Pubmed: 33251559

30. Kubica A. Problems of long-term antiplatelet therapy after coronary stent implantation. Advances in Interventional Cardiology. 2009; 5 158-161

31. Kubica A, Grześk G, Sinkiewicz W, et al. Compliance, concordance, adherence in chronic therapy. Folia Cardiol Excerpta. 2010; 5: 54-57.

32. Kubica A. Collaboration with the patient - a basic condition of therapy effectiveness in coronary artery disease. Chor. Serca Nacz. 2009; 6 $131-134$

33. Kubica A, Gruchała M, Jaguszewski M, et al. Adherence to treatment - a pivotal issue in long-term treatment of patients with cardiovascular diseases. An expert standpoint. Medical Research Journal. 2018; 2(4) 123-127, doi: 10.5603/mrj.2017.0016

34. Kubica A Kosobucka A Michalski P et al Self-reported questionnaires for assessment adherence to treatment in patients with cardiovascular diseases. Medical Research Journal. 2018; 2(4): 115-122, doi 10.5603/mrj.2017.0015
35. Kubica A, Obońska K, Kasprzak M, et al. Prediction of high risk of non-adherence to antiplatelet treatment. Kardiol Pol. 2016; 74(1): 61-67, doi: 10.5603/KP.a2015.0117, indexed in Pubmed: 26101025

36. Polack J, Jorgenson D, Robertson P. Evaluation of different methods of providing medication-related education to patients following myocardial infarction. Canadian Pharmacists Journal. 2008; 141(4): 241-247, doi: 10.3821/1913-701x(2008)141[241:eodmop]2.0.co;2.

37. Kosobucka A Kasprzak M, Michalski P et al. Relation of the Readiness for Hospital Discharge after Myocardial Infarction Scale to socio-demographic and clinical factors. An observational study. Medical Research Journal. 2018; 3(1): 32-37, doi: 10.5603/mrj.2018.0006.

38. Buszko K, Kosobucka A, Michalski P, et al. The readiness for hospital discharge of patients after acute myocardial infarction: a new self-reported questionnaire. Medical Research Journal. 2017; 2(1): 20-28, doi: 10.5603/mri.2017.0004

39. Kubica A, Kosobucka A, Michalski P, et al. The Adherence in Chronic Diseases Scale - a new tool to monitor implementation of a treatment plan. Folia Cardiologica 2017;12:19-26, DOI: 10. 5603/FC. ; 2016: 0000, doi: 10.5603/FC.2016.0000

40. Buszko K, Obońska K, Michalski P, et al. The Adherence Scale in Chronic Diseases (ASCD). The power of knowledge: the key to successful patient - health care provider cooperation. Medical Research Journal. 2016; 1(1): 37-42, doi: 10.5603/mrj.2016.0006.

41. Buszko K, Pietrzykowski $Ł$, Michalski P, et al. Validation of the Functioning in Chronic IIIness Scale (FCIS). Medical Research Journal. 2018; 3(2): 63-69, doi: 10.5603/mrj.2018.0011.

42. Kubica J, Adamski P, Niezgoda P, et al. Prolonged antithrombotic therapy in patients after acute coronary syndrome: A critical appraisal of current European Society of Cardiology guidelines. Cardiol J. 2020 [Epub ahead of print], doi: 10.5603/CJ.a2020.0132, indexed in Pubmed: 33073857.

43. Kubica J, Jaguszewski M. ISAR-REACT 5 - What have we learned? Cardiol J. 2019; 26(5): 427-428, doi: 10.5603/CJ.a2019.0090, indexed in Pubmed: 31536136.

44. Uchmanowicz B, Chudiak A, Uchmanowicz I, et al. Factors influencing adherence to treatment in older adults with hypertension. Clin Interv Aging. 2018; 13: 2425-2441, doi: 10.2147/CIA.S182881, indexed in Pubmed: 30568434

45. Adamski $\mathrm{P}$, Adamska U, Ostrowska $\mathrm{M}$, et al. New directions for pharmacotherapy in the treatment of acute coronary syndrome. Expert Opin Pharmacother. 2016; 17(17): 2291-2306, doi: 10.1080/14656566.2016.1241234, indexed in Pubmed: 27677394

46. Kosobucka A, Pietrzykowski $Ł$, Michalski P, et al. Impact of readiness for discharge from the hospital on the implementation of the therapeutic plan. Medical Research Journal 2020:5 ; 4.

47. Jankowska-Polańska B, Uchmanowicz I, Dudek K, et al. Relationship between patients' knowledge and medication adherence among patients with hypertension. Patient Preference and Adherence. 2016: Volume 10: 2437-2447, doi: 10.2147/ppa.s117269.

48. Uchmanowicz I, Jankowska-Polanska B, Chabowski M, et al. The influence of frailty syndrome on acceptance of illness in elderly patients with chronic obstructive pulmonary disease. Int J Chron Obstruct Pulmon Dis. 2016; 11: 2401-2407, doi: 10.2147/COPD.S112837, indexed in Pubmed: 27729781 